\title{
TINJAUAN ESTETIKA ISLAM PADA KONTRUKSI VISUAL UMOH REJE BALUNTARA SUKU GAYO DI TAKENGON KABUPATEN ACEH TENGAH
}

\author{
Indra Setiawan ${ }^{1 *}$, Haria Nanda Pratama ${ }^{2 *}$, Fani Dila Sari ${ }^{3 *}$ \\ Jurusan Seni Rupa dan Desain ${ }^{{ }^{*}}$, Jurusan Seni Pertunjukan ${ }^{2 \text { dan } 3^{*}}$ \\ Institut Seni Budaya Indonesia (ISBI) Aceh \\ Jl. Transmigrasi, Gampong Bukit Meusara, Kec. Kota Jantho, Kab. Aceh Besar, 23911. \\ Aceh. Indonesia \\ Email: indbrud2@gmail.com
}

\begin{abstract}
Abstrak
Umoh Reje Beluntara Suku Gayo merupakan rumah tempat tinggal raja sebagai ruang aktivitas kesehariannya. Penciptaan rumah adat muara dari segala macam bentuk penghadiran dan penataan untuk mengatur laju kehidupan masyarakat Beluntara Suku Gayo. Kontruksi visual Umoh Reje Baluntara Suku Gayo memperesentasikan nilai-nilai islam sebagai landasan penciptaan sekaligus aktivitas di dalam rumah pada masa lampau. Rerpresentasi Visual Sebagai Simbol Nilai-Nilai Keislaman Pada Umoh Reje Baluntara ditinjau dengan metode penelitian kualitatif. Estetika dengan pedekatan islami mencakup nilai yang terdapat dalam tatanan fungsi ruang dan ornament yang terdapat pada rumah adat reje Baluntara.
\end{abstract}

Kata Kunci: umoh, reje, baluntara, pituruang, gayo.

\begin{abstract}
Umoh Reje Beluntara Gayo tribe is the residence of the king as a space for daily activities. The creation of estuary traditional houses from all forms of presence and arrangement to regulate the pace of life of the Beluntara Gayo people. The visual construction of the Umoh Reje Baluntara Gayo tribe presents Islamic values as a basis for creation as well as activities in the home in the past. Visual representation as a symbol of Islamic values in Umoh Reje Baluntara was reviewed with qualitative research methods. Aesthetics with Islamic approach include the values contained in the spatial order and ornament function found in the Baluntara reje traditional house.
\end{abstract}

Keywords: umoh, reje, baluntara, pituruang, gayo.

\section{PENDAHULUAN}

Suku Gayo memiliki produk-produk budaya yang beraneka, salah satunya adalah Umah Adat Pitu Ruang Reje Baluntara di Takengon Aceh Tengah. Kontruksi visual rumah adat Gayo berupa rumah panggung dengan 36 tiang sebagai penopang bangunan, memiliki tangga masuk berada di luar rumah, tinggi pintu sekitar 1.50 meter. Umah Adat Pitu Ruang Reje Baluntara memiliki ornamen-ornamen pengisi struktur bangunan. Adapun fungsi Umah Adat Pitu Ruang Reje Baluntara tidak hanya sebagai bangunan yang dijadikan tempat tinggal, namun penciptaannya dibangun berdasarkan penerapan nilai-nilai filosofis disetiap kontruksi visual bangunan.

Nilai-nilai yang terkandung dalam ornament yang tampak pada Umah Adat Pitu Ruang Reje Baluntara, nilai-nilai yang mempengaruhi penggunaan jumlah bilangan dalam pembangunan tangga, tiang dan pintu rumah serta nilai-nilai filosofis yang menyebabkan terbangunnya arsiteksur Umah Adat Pitu Ruang Reje Baluntara.

Umah Adat Pitu Ruang Reje Baluntara terbentuk dari idiom nilai-nilai estetis yang hadir pada kontruksi visualnya. Melalui Ajaran nilai-nilai Islam yang meresap pada kebudayaan Gayo, terciptalah sebuah perpaduan antara pembangunan prodak budaya yang mengacu kepada kaidah-kaidah estetis dengan pertimbangan nilai-nilai keislaman. Nilai-nilai keislaman membangun estetika kontruksi visual dengan sisi nilai keislaman yang mengambarkan aturan-aturan yang menyebabkan terjadinya penciptaan struktur Umah Adat Pitu Ruang Reje Baluntara.

\section{KAJIAN TEORI}

Penelitian yang dilakukan pada Umah Reje Beluntara dalam menganalisis ornament yang dikonstruksi oleh motif-motif atau Modul dalam pembangunan visualnya Pendekatan teori dalam penganalisisan adalah sebagai berikut. Mengenai seni tauhid itu, 


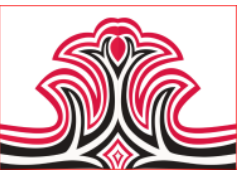

ismail razi Al-faruki menandainya yakni karya seni yang dikategorikan sebagai seni tauhid yang mengusung nilai-nilai secara keislaman mengandung beberapa kriteria didalam ketotalitasan wujut karyanya. Seperti adanya abstraksi, struktur modular, kombinasi subsesif, dinamisme dan kerumitan ${ }^{1}$. Hal ini yang akan dijadikan sebagai sebuah pendekatan dalam menganalisisi penelitian ini.

\section{METODE PENELITIAN}

Metode penelitian ini menggunakan penelitian deskriptif dengan pendekatan etik. Suwardi Endraswara menyatakan bahwa pendekatan etik harus melakukan generalisasi. Pada saat itu, peneliti akan melakukan beberapa hal, yaitu: (1) Pengelompokan secara sistematis seluruh data ke dalam sistem tunggal, (2) menyediakan kriteria untuk klasifikasi setiap unsur data, (3) mengorganisasikan data yang telah diklarifikasikan ke dalam tipe-tipe tertentu, (4) mempelajari, menentukan, dan menguraikan data ke dalam kerangka sistem yang telah dibuat sebelum mempelajari kebudayaan ${ }^{2}$.

Proses analisis data pada Umah Adat Pitu Ruang diperlukan untuk membuktikan ketepatan dan keabsahan sumber data yang sudah dikumpulkan. Tahapan yang dilakukan di mulai dengan melakukan pencarian data, mempelajari, dan mengelompokkan data sehingga memperoleh kesimpulan dan dilanjutkan dengan pencocokan data, sehingga data menjadi lebih valid. Proses ini dibutuhkan dalam mengkaji nilai estetika secara mendalam dan menyeluruh.

\section{HASIL DAN PEMBAHASAN}

\section{Hasil}

Nilai nilai filosofis kebudayaan artinya adalah sebuah kualitas landasan yang menjadi pijakan sitem berfikir dalam menjalani kehidupan yang terungkapkan kedalam bentuk Penciptaan modul-modul sebagai bahasa simbol. Penciptaan visual seni sebagai tuntunan dan tontonan memiliki pengertia bahwa seni berfungsi untuk mempengaruhi rasa secara estetis dan mempengaruhi pemikiran dengan manifestasi maknamakna didalamnya.
Gorga Jurnal Seni Rupa

Volume 09 Nomor 01 Januari-Juni 2020 p-ISSN: 2301-5942 | e-ISSN: 2580-2380

Ornamena adalah kompleksitas hiasan yang digunakan untuk memperindah bagian rumah budaya, pembangunan ornament ini dikonstruksi oleh berbagai macam kolaborasi modul atau motif dalam penghadiran visualnya.

Di dalam seni yang bernuansa Islam ada beberapa kategori yang dapat dikatakan sebagai sarana atau acuan didalam Penciptaan karya seni visualnya yang sesuai dengan nilai-nilai keislaman yang mengajarkan tentan ketuhanan dan kesosialan seperti yang diungkapkan oleh Mengenai seni tauhit itu ismail razi al faruqi yang menandainya dengan abstraksi, struktur modular, kombinasi suksesif, repetisi, dinamisme dan kerumitan:

\section{1).Abstrak}

\section{(1). Puter Tali}

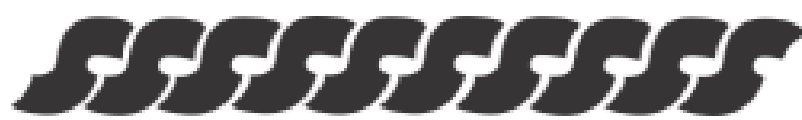

Gambar 1. Puter Tali

(Sumber: Indra Setiawan, 2019)

Modul Puter Tali atau dalam bahasa Indonesia putar tali pilin berganda, merupakan modul yang bersumber dari acuan visual tali yang dipilin secara ganda. Proses pengabtraksian sebagai upaya menyederhanakan bentuk objek acuan tali yang dipilin secara ganda di realitas kedalam Penciptaan bentuk visual modul yang sederhana namun dapat ,mewakili. Hal ini bertujuan untuk memantulkan nilai-nilai filosofis yang terdapal pada modul ini. Penciptaan modul Puter Tali berangkat dari upaya untuk mempresentasikan nilainilai filosofis kedalam Penciptaan visual yang bersumber dari alam sehingga modul ini juga memiliki kekuatan simbolik.

Penyimbolan dihadirkan proses memetaforkan atau perwakilan sesuatu kualitas dengan sesuatu yang lain yang berpotensi untuk mewakilkan, pengungkapan nilai-nilai filosofis pada modul tentang kesatuan , kesepakatan untuk kebaikan pada aktifitas kehidupan diwakilkan dengan modul Puter Tali. 
Tabel 1. Puter Tali

\begin{tabular}{|l|l|}
\hline Puter Tali & Emun Mupesir \\
\hline & \\
\hline Emun Berkune & (2) \\
\hline
\end{tabular}

(2). Emun Mupesir

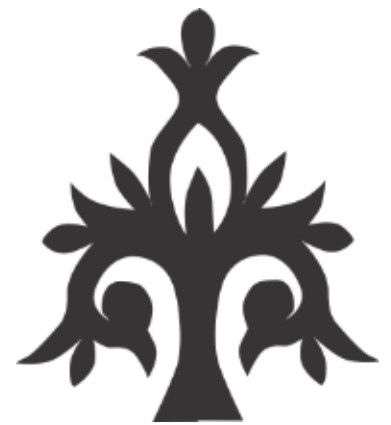

Gambar 2. Emun Mupesir

(Sumber: Indra Setiawan, 2019)

Modul Emun Berkune adalah sebuah motif yang dalam pembentukannya bersumber dari realitas visual celah awan yang menampakkan langit. Penstilisasian atau penyederhananan bentuk dari acuan bentuk visual di realitas digarap dengan pertimbanggan garapan dekoratif, atau menghias sebagai pemunculan estetika atau keindahan. Penciptaan modul Emun Berkune berangkat dari upaya untuk mempresentasikan nilainilai filosofis.

Penyimbolan dalam modul ini dihadirkan dengan proses memetaforkan, pengungkapan nilai-nilai filosofi Demokra si, bertanggungjawab dan putunjuk arah diwakilkan dengan modul Emun Berkune.

\section{(3). Emun Berkune}

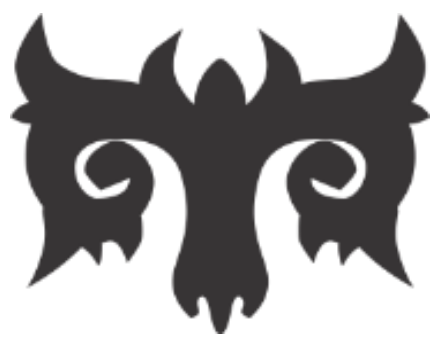

Gambar 3. Emun Berkune

(Sumber: Indra Setiawan, 2019)

Modul Emun Berkune adalah sebuah motif yang bersumber dari penglihatan terhadap celah awan yang menampakkan langit. Penstilisasian atau penyederhananan bentuk dari acuan bentuk visual di
Gorga Jurnal Seni Rupa

Volume 09 Nomor 01 Januari-Juni 2020

p-ISSN: 2301-5942 | e-ISSN: 2580-2380

realitas digarap dengan pertimbanggan garapan dekoratif, atau menghias sebagai pemunculan estetika atau keindahan.

Penciptaan modul Emun Berkune berangkat dari upaya untuk mempresentasikan nilai-nilai filosofis kedalam Penciptaan visual. pengungkapan nilai-nilai filosofi Demokrasi, bertangg ung jawab dan putunjuk arah diwakilkan dengan modul Emun Berkune.

\section{2).Struktur Modular}

Berdasarkan hasil analisi dan data temuan dari narasumber dilapangan, beberapa modul-modul yang dimuati oleh makna-makna filosois di ornament Umah Reje Baluntura, teridentifikasi sebagai:

Tabel 2. Struktur Modular

\begin{tabular}{|c|c|}
\hline Puter Tali & 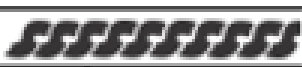 \\
\hline Emun Mupesir & \\
\hline Emun Berkune & \\
\hline
\end{tabular}

3).Kombinasi Subsesif

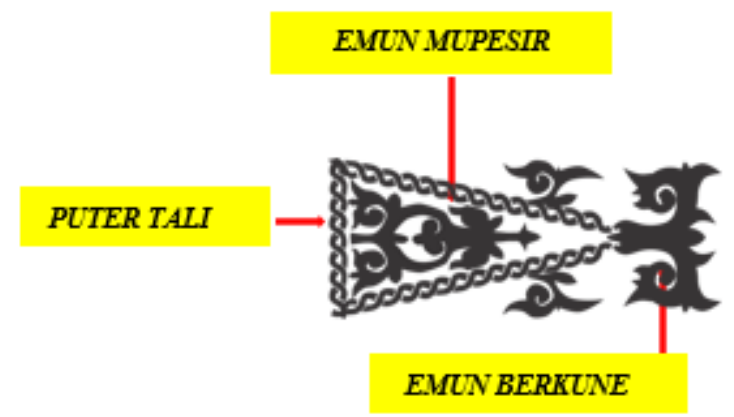

Gambar 4. Kombinasi Suksesif pada Ornamen Umah Reje Beluntara Modul Emun Mupesir, Modul Pilin Talie dan Modul Emun Berkune.

(Sumber: Indra Setiawan, 2019)

\section{4).Repetisi}

Repetisi yang terdapat di ornament pada Umah Reje Beluntara berdasarkan hasil analisis melalui pendekatan teori dapat dijelaskan bahwa salah- satu modol-modul di Umah Adat Pitu Ruang seperti Modul Emun Mupesir dan Modul Pilin Talie, digarap dengan pola pembentukan repetisi secara horizontal. Didalam karya ornamen Umah Reje Beluntara yang salah satu sisi penggarapan modulnya dapat terlihat repetisi yang telah terhadirkan dari perwakilan beberapa contoh modul beikut ini: 


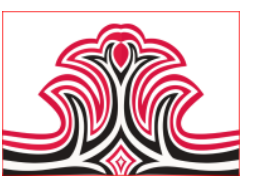

Tabel 3. Repetisi

\begin{tabular}{|c|c|}
\hline 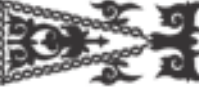 & 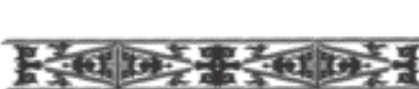 \\
\hline $\begin{array}{c}\text { Kombinasi } \\
\text { Subsesif }\end{array}$ & Repetisi \\
\hline
\end{tabular}

\section{5).Dinamisme}

Karya visual ini bukan hanya berbicara tentang estetik, dan penyimbolan makna saja, Akan tetapi yang juga penting adalah proses mengalami karya beserta pemahaman yang telah dimiliki dan disepakati segenap masyarakatnya. Proses mengalami, memahami dan merasakan adalah suatu dinamika dan proses dialektis budaya dalam mentransfer ajaran untuk aktifitas kehidupan. dinamisme merupakan proses mengalami secara serial dan komulatif.

Umah Reje Beluntara pada saat ini sudah beralih fungsi dari sebelumnya rumah tempat tinggal raja dan sekarang menjadi sebagai tempat objek wisata budaya, yang dilindungi oleh pemerintah. Sehingga hasil analisis yang didapatkan tentang dinamisme yang pertama bahwa Umah Reje Beluntara adalah tempat yang sudah dialih fungsikan sebagai tempat wisata budaya, hal ini menjadikan tidak adanya aktifitas dialektis pengghuninya pada rumah ini, sehingga untuk pewarisan nilai dengan sistem mengalami, memahami dan merasakan sudah tidak menjadi aktifitas yang berlanjut yang dialami dari waktu-kewatu.

\section{6).Kerumitan}

Karya ornament yang diciptakan pada Umah Reje Beluntara digarap dengan mengkolaborasikan modulmodu sebagai sebuah struktur yang padu. Masingmasing Modul merupakan wujut atau simbol dari penanaman nilai-nilai ajaran kehidupan. Kerumitan pada karya budaya ini terbagi menjadi dua pembagian.

Pertama dari segi kerumitan penciptaan secara fisik. Karya ornamen ini diciptakan dengan teknik pahat pada kayu Medang Jeumpa dimana kayu ini adalah kayu yang memiliki kualitas yang terbaik di dataran tinggi gayo. Dalam penggarapan ornament ini dalam pembentukan Modulnya telah memiliki sifat yang terabstrakasi dengan proses stilisasi dan dihadirkan dalam bentuk dekoratif sebagai capaain estetiknya. Pengkolaborasian Modul-modul untuk membangun ornament secara keseluruhan dibangun dengan pengkomposisian pola geometric secara horizontal. Proses pengkomposisian Modul-modul untuk membangun struktur ornament, diciptakan dengan merepetisi modul-modul sehingga terciptalah struktur besar ornament ini yang memiliki energy gangguan
Gorga Jurnal Seni Rupa

Volume 09 Nomor 01 Januari-Juni 2020

p-ISSN: 2301-5942 | e-ISSN: 2580-2380

yang besar secara visual.

Kedua adalah pengungkapan nilai-nilai kedalam bentuk simbolik. Pengungkapan ini melalui proses memetaforkan antara nilai-nilai ajaran yang ingin disampaikan dengan sebuah Motif yang akan digunakan bebagai penyampaian bahasa visual. Penyamaan suatu kualitas antara apa yang ingin disampaikan dengan penyampainya didapatkan dengan mempelajari alam dan lingkungan sekitar melalui kacamata budaya dan agama dan menyesuaikannya dengan kualitas objek realitasnya yang diamati, sehingga terciptalah modul yang dapat mewakilkan nilai-nilai tersebut. Selanjutnya motif simbolik yang teridentifikasi pada penelitian ini di kolaborasikan untuk membentuk ornament yang kompleks, artinya motif-motif yamng masing- masing memiliki pengertian tentang makna dan nilai yang tertanam didalam masing-masingya di kolaborasikan untuk membangun struktur ornament secara utuh sehingga terciptalah energy yang besar dari ornament yang memiliki banyak makna-makna ajaran tentang kehidupan didalamnya.

\section{KESIMPULA DAN SARAN}

\section{Kesimpulan}

Estetika dengan pedekatan islami mencakup nilai yang terdapat dalam tatanan fungsi ruang yang terdapat pda rumah adat reje Baluntara. Semangat keislaman tercermin dari pembagian wilayah ruang perempuan dan laki-laki. Secara simbolis terlihat pada ornament yang terdapat pada sisi rumah adat, misalnya simbol fauna dan flora. Hal ini yang dilakukan peneliti untuk meninjau sejauh apa konstruki visual nilai islam yang terdapat pada rumah adat Reje Baluntra.

\section{Saran}

Karya seni rupa tradisional adalah karya yang mengidentifikasi karakteristik proses penciptaannya, sehingga proses analisis didukung oleh teori-teori yang sesuai dengan konten tradisional sebagai upaya penelusuran dan pengungkapan ornament-ornamen lokalitas. Artinya penciptaan karya seni rupa tradisional dilatarbelakangi oleh cara berfikir masyarakatnya. Diharapkan kedepannya penelitianpenelitian yang membahas dan mengkaji karya seni rupa tradisional ditelaah dari berbagai perspektif yang baru sebagai sarana ungkap kekhasan nilai dan makna tradisional tersebut.

\section{DAFTAR RUJUKAN}

Endraswara, Suwardi. (2006). Metode, Teori, Teknik, Penelitian Kebudayaan. Yogyakarta: Pustaka Widyautama. 
Sabana, Setiawan. ( ). Tapak Seni Rupa Nusantara. Bandung: ITB Press.

Salihin, Ansar. (2019). Motif Ukiran Kerawang Gayo Pada Rumah Adat Gayo di Kabupaten Aceh Tengah Provinsi Aceh. Gorga Jurnal Seni Rupa, 08(01), 287-300. 